\title{
Penyelesaian Perkara Kecelakan Lalu Lintas Di Jalan Raya
}

\author{
${ }^{1}$ Muhammad Afzal \& ${ }^{2}$ Rahmad Hidayat \\ ${ }^{1}$ Universitas Mahasaraswati Mataram; ${ }^{2}$ Universitas Muhammadiyah Mataram \\ Email: ${ }^{1}$ afzalalex369@gmail.com; ${ }^{2}$ rahmad_dayat22@yahoo.com
}

\begin{abstract}
Abstrak; Tujuan dari penelitian ini adalah: (a), Untuk Mengetahui bagaimanakah upaya pencegahan dalam meminimalisir kecelakaan lalu lintas (b) untuk mengetahui bagaimanakah penyelesaian perkara kecelakaan Lalu Lintas. Penelitian ini bermanfaat untuk memberikan bekal pengetahuan dalam mengkaji atau menerapkan suatu ilmu pengetahuan hukum khususnya hukum pidana, hukum acara pidana, melalui suatu tindakan empiris di lapangan/masyarakat. Sedangkan secara praktis, bahwa hasil peneltian ini akan dapat dimanfaatkan sebagai suatu masukan atau sumbangan pemikiran bagi pejabat / aparat terkait untuk meningkatkan kualitas pelaksanaan tugas, khususnya dalam penerapan peraturan hukum yang berlaku bagi kasus-kasus serupa. Hasil penelitian menunjukkan bahwa: Secara yuridis tugas dan wewenang Polri telah diatur dalam konstitusi dan berbagai peraturan perundang-undangan. Ketentuan yuridis sebagaimana termuat dalam Pasal 30 ayat (4) Undang-Undang Dasar Tahun 1945,dan Undang-Undang Nomor 2 Tahun 2002 tentang Kepolisian Republik Indonesia menegaskan "Polri sebagai alat Negara yang menjaga keamanan dan ketertiban bertugas melindungi, mengayomi, melayani masyarakat, serta menegakkan hukum". Hal senada dengan ketentuan Pasal 6 KetetapanMPR No.VII/MPR/2000 Tentang Peran TNI dan Polri, "Polri merupakan alat Negara yang berperan dalam memelihara keamanan dan ketertiban masyarakat, menegakkan hukum, memberikan perlindungan, pengayoman dan pelayanan kepada masyarakat".
\end{abstract}

Kata Kunci: Perkara, Kecelakanaan, Lalu Lintas.

Abstract; The objectives of this study are: (a), To find out how prevention efforts are in minimizing traffic accidents (b) to find out how the completion of a Traffic accident case. This research is useful to provide knowledge in studying or applying a legal science, especially criminal law, criminal procedure law, through an empirical action in the field / society. While practically, the results of this study will be utilized as an input or contribution to the thought of officials / related officials to improve the quality of the implementation of tasks, especially in the application of applicable legal regulations for similar cases. The results of the study show that: Juridically the duties and authorities of the National Police are regulated in the constitution and various laws and regulations. The juridical provisions as contained in Article 30 paragraph (4) of the 1945 Constitution, and Law Number 2 of 2002 concerning the Republic of Indonesia Police affirm that "the National Police as a State instrument that maintains security and order has the duty to protect, protect, serve the community, and enforce the law ". Similar to the provisions of Article 6 of the Decree of MPR No.VII / MPR / 2000 concerning the Role of the TNI and Polri, "Polri is a State tool that has a role in maintaining security and public order, enforcing the law, providing protection, protection and service to the community".

\section{PENDAHULUAN}

Saat ini kualitas citra Polisi Republik Indonesia dinilai mengalami kemerosotan dimata masyarakat. Kemerosotan citra Polri tersebut merupakan sebuah persoalan penting yang hingga saat ini masih terus membelenggu Polri dalam menjalankan tugas dan wewenangnya sebagai penjaga keamanan dan ketertiban masyarakat, melakukan penegakan hukum, dan melakukan pengayoman, perlindungan serta menciptakan keamanan, ketertiban dan kelancaran lalu lintas dalam melayani masyarakat. Ketentuan yuridis tentang peran Polri yang demikian itu, kemudian dijabarkan lebih lanjut dalam Pasal 5 Undang-Undang Nomor 2 Tahun 2002 tentang Kepolisian Republik Indonesia tentang Polri menegaskan bahwa :

Pasal 5 menegaskan : 
1. Kepolisian Negara Republik Indonesia merupakan alat negara yang berperan dalam memelihara keamanan dan ketertiban masyarakat, menegakkan hukum, serta memberikan perlindungan, pengayoman, dan pelayanan kepada masyarakat dalam rangka terpeliharanya keamanan dalam negeri.

2. Kepolisian Negara Republik Indonesia adalah Kepolisian Nasional yang merupakan satu kesatuan dalam melaksanakan peran sebagaimana dimaksud dalam ayat (1).

Bertolak dari ketentuan yuridis tersebut tampak, bahwa lembaga kepolisian di Indonesia tidak hanya berperan sebagai bagian dari penegakan hukum yang terpola dalam Sistem Peradilan Pidana (SPP), melainkan lebih jauh dari itu berperan juga sebagai lembaga penjaga keamanan dan ketertiban masyarakat, serta pelindung, pengayom dan pelayan masyarakat.

Upaya untuk menata dan meningkatkan kesejahteraan anggota Polri dalam konteks Reformasi Birokrasi di lingkungan Polri merupakan kebutuhan yang sangat elementer, mengingat kaitannya yang sangat erat dengan misi perubahan kultur Polri (Reformasi bidang kultural). Sehingga dengan struktur gaji yang baru (nanti), setiap anggota Polri diharapkan akan mempunyai daya tangkal (imunitas) yang maksimal terhadap rayuan atau iming-iming materi (kolusi).Kinerja kepolisian tidak hanya terbatas pada hal-hal yang telah diuraikan di atas. Persoalan tertib berlalu lintas merupakan pekerjaan rumah yang harus diselesaikan oleh kepolisian. Meningkatnya angka kecelakaan lalu lintas di Indonesia pada umumnya dan dari tahun ke tahun, menjadi sinyal bagi kepolisian untuk meningkatkan kinerja dan profesionalitas sebagai salah satu aparat penegak hukum yang bertugas menertibkan lalu lintas dan angkutan jalan.

Kinerja kepolisian dalam upaya menertibkan lalu lintas dan angkutan jalan didukung dengan ketentuan perundangundangan yaitu Undang-undang Republik Indonesia Nomor 22 Tahun 2009 Tentang Lalu Lintas dan Angkutan Jalan sebagai pengganti Undang-undang Nomor 14 Tahun 1992 Tentang Lalu Lintas dan Angkutan
Jalan. Undang-undang Nomor 14 Tahun 1992 diganti karena sudah tidak sesuai lagi dengan kondisi, perubahan lingkungan strategis, dan kebutuhan penyelenggaraan lalu lintas dan angkutan jalan saat ini dalam mengatur kebutuhan masyarakat dalam berlalu lintas.

Pengaturan dan penerapan sanksi pidana dalam Undang-undang Lalu Lintas diatur lebih tegas. Bagi pelanggar yang sifatnya ringan dikenakan sanksi pidana kurungan/denda yang relatif lebih ringan dan terhadap pelanggaran berat dan terdapat unsur kesengajaan dikenakan sangsi pidana yang jauh lebih berat. Pelaksanaan dan penerapan Undang-undangNomor 22 Tahun 2009 Tentang Lalu Lintas dan Angkutan Jalan di Kota Mataram berlaku secara keseluruhan bagi pengguna kendaraan. Pelaksanaan dan penerapan Undang-undang Lalu Lintas tersebut berdampak pada ketaatan, ketertiban berkendaraan di jalan raya, serta tidak terlepas kemungkinan adanya risiko kecelakaan lalu lintas terus meningkat, yang pada akhirnya menimbulkan tindak pidana lalu lintas dan angkutan jalan

\section{RUMUSAN MASALAH}

1. Bagaimanakah upaya pencegahan dalam meminimalisir kecelakaan lalu lintas ?

2. Bagaimanakah penyelesaian perkara kecelakaan Lalu Lintas?

\section{METODE PENELITIAN}

Jenis Penelitian ini merupakan penelitian normatif-empiris karena penelitian ini menitikberatkan pada penelitian secara menyeluruh, sistematis, faktual dan aktual mengenai fakta-fakta yang berhubungan dengan masalah yang akan diteliti.Pelaksanaan penelitian ini melalui dua tahap yaitu penelitian kepustakaan guna mendapatkan data sekunder dan penelitian lapangan untuk memperoleh data primer.

\section{Cara dan Alat Pengumpulan Data a. Teknik Pengambilan Sampel}

Setelah peneliti merumuskan permasalahan, tujuan, dan rancangan penelitian dengan tepat dan benar, maka tahap selanjutnya adalah menentukan objek penelitian dari mana data akan dikumpulkan. Idealnya data dikumpulkan dari semua obyek yang dipermasalahkan, akan tetapi hal ini tentu sangat banyak membutuhkan biaya, tenaga dan waktu, sehingga karenanya tidak 
efisien, oleh karena itu dalam suatu penelitian pada umumnya hanya menggunakan sebagian saja dari keseluruhan obyek penelitian, jadi lokasi yang dijadikan sampel yaitu Polres Mataram. Dalam penelitian ini jenis sampel yang digunakan adalah teknik non-random sampling, yaitu tidak semua individu diberi kesempatan untuk menjadi anggota sampel. Jenis sampel yang diinginkan adalah purposive sampling, yaitu mempunyai hubungan erat dan khusus dengan pengetahuan yang cukup serta ciri-ciri tertentu yang berhubungan dengan permasalahan yang diteliti.

\section{b. Alat Pengumpulan Data}

Cara pengumpulan data yang digunakan dalam penelitian ini adalah wawancara, yaitu pengumpulan data yang dilakukan secara lisan dengan mengajukan pertanyaan secara langsung pada responden yang berhubungan dengan masalah yang akan diteliti. Wawancara dilakukan secara terstruktur dengan berpedoman pada daftar pertanyaan yang sudah disiapkan terlebih dahulu. Alat yang dipergunakan untuk penelitian kepustakaan adalah studi dokumen terhadap bahan hukum primer, bahan hukum sekunder dan bahan hukum tersier sebagaimana telah diuraikan sebelumnya. Alat pengumpulan data yang dipergunakan pada saat penelitian lapangan adalah interview, yang berupa pedoman wawancara yang bersifat terbuka dan sistematis yang disusun berdasarkan masalah yang akan diteliti. Pedoman wawancara hanya berupa garis besarnya saja sehingga tidak menutup kemungkinan adanya pertanyaan lain sepanjang masih berhubungan dengan masalah yang diteliti.

\section{Analisis Data}

Menganalisis data yang telah diperoleh dari hasil penelitian lapangan dengan menggunakan metode analisis deskriptif kualitatif, yaitu dengan menjelaskan atau menggambarkan sesuatu yang diperoleh dari teori maupun dari hasil seleksi kemudian dihubungkan dengan peraturan hukum yang ada, sehingga mendapatkan jawaban dari permasalahan yang diteliti.

\section{HASIL PENELITIAN DAN PEMBAHSAN \\ 1.Upaya Pencegahan Dalam Meminimalisir Kecelakaan Lalu Lintas}

Pembentuk undang-undang kita menggunakan istilah straafbaarfeit untuk menyebutkan nama tindak pidana, tetapi tidak memberikan penjelasan secara rinci mengenai straafbaarfeit tersebut.

Dalam bahasa Belanda straafbaarfeit terdapat dua unsur pembentuk kata, yaitu staafbaar dan feit. Perkataan feit dalam bahasa Belanda diartikan "sebagian dari kenyataan", sedang straafbaar berarti "dapat dihukum", sehingga secara harfiah perkataan straafbaarfeit berarti "sebagaian dari kenyataan yang dapat dihukum" yang sudah tentu tidak tepat. Oleh karena itu, kelak akan kita ketahui bahwa yang dapat duhukum adalah manusia sebagai pribadi bukan kenyataan, perbuatan, atau tindakan.

Moeljatno, dalam bukunya Asas-asas Hukum Pidana memberikan pengertian tentang tindak pidana.

"Perbuatan yang dilarang oleh suatu aturan hukum, larangan yang mana disertai sanksi berupa pidana tertentu bagi barang siapa yang melanggar aturan tersebut. Dapat juga dikatakan bahwa perbuatan pidana adalah perbuatan yang dilarang hukum dan diancam pidana asal saja dalam hal itu diingat bahwa larangan ditujukan pada perbuatan (yaitu keadaan atau kejadian yang ditimbulkan oleh kelakukan orang, sedang ancaman pidananya ditujukan pada orang yang menimbulkan kejaatan)".

Untuk adanya perbuatan pidana harus ada unsur-unsur: (1) perbuatan (manusia), (2) memenuhi rumusan dalam undang-undang (syarat formil), (3) bersifat melawan hukum (syarat materiil). Syarat formil harus ada, karena asas legalitas dalam Pasal 1 ayat (1) KUHP.

Moeljatno, juga merumuskan unsurunsur perbuatan pidana menjadi lima unsur atau elemen perbuatan pidana :

1) Kelakuan dan akibat.

2) Hal ikhwal atau keadaan yang menyertai perbuatan .

3) Keadaan tambahan yang memberatkan pidana. 
4) Unsur melawan hukum yang obyektif.

5) Unsur melawan hukum yang subyektif.

Isi definisi hukum pidana dari Moeljatno dengan sepintas lalu tidak berbeda dengan definifsi hukum pidana menurut ungkapan Van Apeldoorn, terutama di dalam menentukan kerangka hukum yang dicakup oleh pengertian hukum pidana. Pendapat umum sudah menerima istilah hukum pidana diartikan sebagai hukum pidana materiel saja.

Tindak Pidana/Pelanggaran Lalu Lintas dan Angkutan Jalan, Sudarto, dalam tulisan; "Perkembangan Masyarakat dan Pembentukan Hukum Pidana", mengemukakan bahwa pada rentetan jenis kejahatan (tindak pidana) yang berbarengan dengan berkembangnya masyarakat (modern) itu dapat ditambahkan jenis tindak pidana yang tidak boleh dianggap enteng yang pada hakikatnya sangat merugikan masyarakat, ialah pelanggaran lalu-lintas.

Terhadap tindak pidana/pelanggaran lalu lintas dilakukan upaya penanggulangan dilakukan baik secara preventif melalui operasi rutin/razzia dan operasi khusus, maupun secara represif melalui sidang pengadilan. Dari data pelaku pelanggaran dapat diklasifikasi dalam usia dan jenis pekerjaan. Berdasarkan usia, maka usia antara 16 tahun hingga 30 tahun menempati urutan teratas dalam pelanggaran lalu lintas, sementara dari jenis pekerjaan, swasta dan pelajar menempati urutan teratas dalam pelanggaran lalu lintas. Keadaan di atas membuktikan kualitas kesadaran hukum masyarakat (pemakai jalan) belum memenuhi himbauan disiplin nasional. Upaya Polri dalam penegakkan bidang lalu lintas juga dilakukan dengan melakukan tindakan "menegur" pelaku atas "peringatan" oleh Polri di jalan

Pelaksanaan tugas kepolisian secara umum Polri melakukan patroli rutin pada seluruh wilayah penugasan dan mengambil langkah-langkah pengaturan/pengamanan kegiatan publik termasuk menjamin ketertiban lalu lintas. Lalu lintas dan angkutan jalan raya memegang peranan yang sangat penting dan strategis bagi perkembangan masyarakat sehingga dengan demikian segala hal yang berkaitan dengan lalu lintas akan luas dan kompleks.Hampir setiap hari manusia melakukan kegiatannya sehari-hari mempergunakan jalan raya. Jalan raya merupakan jalan dalam bentuk apapun yang terbuka untuk lalu lintas umum sudah merupakan salah satu kebutuhan bagi masyarakat. Warga yang hendak menggunakan jalan raya tersebut harus menaati peraturan-peraturan mengenai lalu lintas maupun angkutan jalan raya. Penggunaan jalan raya sebagai salah satu kebutuhan pokok warga masyarakat agar benar-benar berfungsi maka diperlukan pengaturan-pengaturan tertentu mengenai ketertiban, keamanan maupun keselamatannya.

Menurut H.L.Yoesuf jika dilihat dari garis besar maka Undang-undang Nomor 22 Tahun 2009 mempunyai keunggulan dibanding dengan Undang-Undang Nomor 14 tahun 1992, keunggulan-keunggulan tersebut antara lain:

a. Mengatur transportasi sampai keseluruhan pelosok tanah air.

b. Mengatur penggunaan dan penyelenggaraan terminal.

c. Mengatur pengadaan fasilitas perparkiran guna memperlancar lalu lintas di kota-kota besar.

d. Mengatur ketentuan pengangkutan barang berbahaya, beracun dan alat berat guan mendukung kemajuan industri, dagangan, dan menjamin keselamatan penggunaannya.

e. Mengatur ketentuan kendaraan untuk orang cacat.

f. Mengatur ketentuan penggunaan sabuk pengaman, baik pengemudi maupun yang duduk disampingnya.

g. Mengatur ketentuan asuransi kendaraan bermotor dan awaknya.

h. Mengatur ketentuan pengendalian dampak lingkungan.

i. Mengatur ketentuan rekayasa dan manajemen lalu lintas.

j. Memberikan perlindungan kepada pejalan kaki.

k. Mengatur ketentuan mengenai ketegasan pemberian hak dan tanggungjawab masing-masing pihak yang bersangkutan.

1. Mengatur ketentuan tanggungjawab terhadap korban kecelakaan. 
m. Mengatur ketentuan tanggungjawab pengusaha bila terjadi pembatalan.

n. Mengatur ketentuan angkutan lalu lintas.

o. Mengatur ketentuan tanggungjawab pihak ketiga.

p. Mengatur lebih tegas tentang pemeriksaan dan penyidikan kedaraan bermotor.

q. Mengatur lebih terperinci tentang sanksi pelanggaran.

Menurut Awaloedin pelanggaran lalu lintas adalah: Merupakan pelanggaran terhadap keamanan dan ketertiban umum maka pribadi yang memperoleh sanksi hukuman yang terlalu ringan akan merasa bahwa pelanggaran lalu lintas yang dilakukan diaggap terlalu ringan sifatnya sehingga rasa bersalah (sence of guilty) sangat tipis, terutama pribadi-pribadi yang digolongkan sebagai pengemudi ugal-ugalan di jalan raya". Akibat ketimpangan antara peningkatan frekuensi dan volume lalu lintas jalan dengan keterbatasan sarana dan prasarana lalu lintas menimbulkan persoalan baru dalam lalu lintas jalan, dan persoalan yang dihadapi menjadi semakin rumit lagi dengan menurunnya disiplin serta sopan santun dalam berlalu lintas para pemakai jalan, sebab menurunnya disiplin dan sopan santun dalam berlalu lintas cenderung akan menimbulkan terjadinya pelanggaran lalu lintas maupun kecelakaan lalu lintas. Oleh sebab itu perlu dilakukan upaya penanggulangan untuk mengatasi segala permasalahan dibidang lalu lintas tersebut, yang harus dilakukan secara maksimal dan berkesinambungan, baik oleh POLRI maupun instansi-instansi yang berkaitan dengan tugastugas dibidang lalu lintas dan angkutan jalan.

Karenanya diperlukan adanya fasilitas transportasi yang dapat menopang kegiatan dan mobilitas masyarakat yang semakin berkembang tersebut. Kebutuhan penyediaan sarana transportasi yang menunjang tersebut tidak dapat berdiri sendiri melalui peran satu pihak saja. Diperlukan adanya peran serta antara Dinas Perhubungan yang berperan sebagai manajemen transportasi, Dinas Pekerjaan Umum sebagai bidang penyedia prasaraan jalan, dan POLRI yang berperan sebagai lembaga penegak hukum. Peran serta ketiga lembaga tersebut dapat menciptakan suatu tujuan terbentuknya sistem transportasi yang aman, lancar, tertib. Perhubungan sendiri adalah suatu tataran sistem penyelenggaraan transportasi darat maupun perairan daratan yang saling berkaitan satu sama lain dan berintregasi secara keseluruhan dengan ruang lalu lintas (jalan, jembatan, dan atau rel) yang berada di bawah sistem otonomi daerah. Dinas Perhubungan adalah suatu lembaga yang terdiri secara mandiri dalam melaksanakan peran pelaksanaan kebijakan berdasarkan pemerintahan otonomi daerah.

Dengan adanya otonomi daerah memberikan desentralisasi pada Dinas Perhubungan untuk melaksanakan otonomi seluasluasnya berikut semua aparatur dan keuangannya kecuali hal-hal yang bersifat nasional yang akan diatur dan undang-undang

DISHUB (DLLAJR) adalah lembaga yang berdiri berdasarkan desentralisasi. Desentralisasi di sini mengandung pengertian pelepasan diri dari pusat, atau pelimpahan kekuasaan pemerintah dari pusat pada daerahdaerah yang mengurus rumah tangganya sendiri (daerah otonom)

Namun tidak banyak pula pihak yang dapat mengapresiasi peran Dinas Perhubungan (DLLAJR) dengan segala kewenangan dan fungsinya. Sering kali hanyalah fungsi teknis lapangan saja yang dipahami oleh masyarakat. Contoh tindakan teknis yang paling banyak diketahui oleh masyarakat adalah kegiatan mengatur lalu lintas jalan, penggantian lampu traffic light, pemasangan rambu lalu lintas, menilang angkutan umum yang melanaggar peraturan (menarik retribusi), atau kegiatan teknis lapangan lainnya.

\section{Penyelesaian Perkara Kecelakaan Lalu Lintas}

Di dalam Amandemen Kempat Undang-Undang Dasar Negara Republik Indonesia Tahun 1945, pada Pasal 28D ayat (1) menyatakan bahwa "Setiap orang berhak atas pengakuan, jaminan, perlindungan, dan kepastian hukum yang adil serta perlakuan yang sama di hadapan hukum". Dalam kaitannya dengan sistem penyelesaian sengketa.

Di Indonesia sendiri pada dasarnya penyelesaian suatu sengketa dapat dilakukan melalui 2 (dua) proses, yaitu penyelesaian 
sengketa melalui proses Litigasi dan proses Non Litigasi. Proses Litigasi adalah penyelesaian masalah hukum melalui jalur pengadilan.

Penyelesaian sengketa melalui proses non litigasi yaitu menyelesaikan masalah hukum di luar pengadilan. Proses non litigasi ini dikenal dengan penyelesaian Sengketa Alternatif, yang terdiri dari mediasi, negosiasi dan arbitrase. Melalui proses di luar pengadilan ini menghasilkan kesepakatan yang bersifat "win-win solution", yaitu menganut prinsip sama-sama menguntungkan.

a. Upaya Preventif.

Upaya preventif merupakan upaya pihak kepolisian untuk mencegah terjadinya tindak pidana. Upaya preventif memang menjadi kinerja yang wajib dilakukan oleh semua anggota POLRI karena upaya preventif lebih diutamakan dan merupakan perintah dari pejabat tinggi POLRI dengan harapan dalam bekerja lebih baik mencegah terjadinya tindak pidana dari pada menangani suatu tindak pidana yang terlanjur terjadi. Upaya upaya tersebut antara lain :

1) Melakukan pembinaan dan pendidikan pada masyarakat

2) Melakukan sosialisasi di tempat-tempat strategis..

3) Membuat dan Menjalankan program program yang berfungsi mengajak masyarakat atau membuat masyarakat untuk mematuhi peraturan lalu lintas termasuk. Program-program yang ada seperti :

a) Safety Award Room (SAR).

Program tersebut dilakukan kepada semua pihak yang melakukan pemohonan pembuatan surat ijin mengemudi (SIM).

b) Mengumpulkan dan Melakukan pelatihan

Upaya mengumpulkan dan melakukan pelatihan yang dilakukan tersebut pihak polisi bekerja sama dengan pihak dinas perhubungan dengan mengumpulkan semua sopir maupun supir angkutan kota secara berkala bertempat di polres.

b. Upaya preventif

sebagai upaya pencegahan dilakukan polisi sebaik mungkin karena polisi ingin mengurangi terjadinya tindak pidana lalu lintas oleh para pengemudi bahkan menghilangkan hal tersebut sampai kepada zeroaccident yaitu tidak ada kasus yang terjadi. Dalam upaya tersebut polisi ingin berada di depan rambu-rambu, maksud dari istilah tersebut adalah polisi ingin bergerak atau bekerja sebelum tindak pidana lalu lintas itu terjadi tanpa harus menunggu tindak pidana lalu lintas tersebut telah terjadi.

c. Upaya Represif

Upaya represif adalah upaya yang dilakukan oleh pihak kepolisian untuk menanggulangi terjadinya tindak pidana, dalam hal ini adalah tindak pidana dalam lalu lintas. Upaya yang dilakukan antara lain yaitu sesuai dengan menerapkan hukum yang berlaku yaitu dengan KUHP atau juga Undang-Undang Nomor 22 tahun 2009 tentang lalu lintas dan angkutan jalan. Penerapan aturan hukum dengan KUHP atau UU Nomor 22 tahun 2009 tentang lalu lintas dan angkatan jalan bertujuan agar tidak salah dalam menerapkan pada tindak pidana yang dilakukan. Dalam kasus kecelakaan, kepolisian akan menerapkan pasal 359 KUHP apabila korban dari kecelakaan tersebut meninggal dunia, sedangkan apabila korbannya mengalami luka ringan maupun luka berat diterapkan pasal 360 ayat 1 KUHP dan apabila korban luka hingga cacat dalam waktu tertentu maka diterapkan pasal 360 ayat 2 KUHP.

\section{KESIMPULAN}

1. Upaya-upaya dalam mencegah terjadinya tindak pidana lalu lintas sebagai awal terjadinya suatu kecelakaan lalu lintas, yaitu : Rekayasa atau Manajemen Lalu Lintas, Mengadakan Patroli Gabungan, Survey Gabungan, Upaya Preventif dan Upaya Represif.

2. Faktor kendala yang dihadapi dalam mencegah terjadinya pelanggaran lalu lintas di wilayah hukumnya yang dialami adalah : Kendala Internal, meliputi : Kurangnya Sosialisai Kepada Masyarakat, Terbatasnya Anggaran, Kurangnya Sarana dan Prasarana. Sedangkan Kendala Eksternal, meliputi :Kurangnya kerjasama antara DLLAJR dan polisi lalulintas dengan instansi lain yang berkaitan dengan lalu lintas dan Rendahnya Tingkat Kesadaran Hukum Pengendara. 


\section{SARAN}

1. DLLAJR dan kepolisian sebaiknya meningkatkan pengadaan patrol atau raziarazia lalu lintas dengan tujuan agar masyarakat lebih berdisiplin diri dalam kegiatan berlalulintas, serta meningkatkan pelayanan sosialisasi dan penyuluhan kepada seluruh lapisan masyarakat tentang tata cara berlalulintas yang baik dan benar.

2. Bagi masyarakat pengguna jalan raya, untuk lebih meningkatkan kesadaran hukum dalam bentuk meningkatkan pengetahuan berlalulintas yang baik dan benar guna untuk mencegah dan mengurangi terjadinya kecelakaan lalulintas.

\section{DAFTAR PUSTAKA}

Abdurrahman. Beberapa Pemikiran Tentng Otonomi Daerah, Jakarta: Media Sarana Perss. 1987.

Awaloedin, 1983, Peningkatan Disiplin Masyarakat Pemakai Jalan Raya dalam Kaitannya dengan Wewenang Polri sebagai Penegak Hukum, Surabaya, Binallmu,.

Bambang Poernomo. 1985, Asas-asas Hukum Pidana, Jakarta: Ghalia Indonesia.

C.S.T. Kansil, Hukum Tata Pemerintahan Indonesia, Jakarta : Ghalia Indonesia. 1984.

Evi Hartanti. 2005. Tindak Pidana Korupsi. Jakarta : Sinar Grafika.

H.L. Yoesuf, 2013. Penyuluhan Hukum Tentang Lalu Lintas dan Angkutan Jalan. (Mataram, Dinas Lalu Lintas dan Angkutan Jalan Provinsi Nusa Tenggara Barat).

M. N. Nasution, Manajemen Transportasi, Bogor: Ghalia Indonesia, 2008

Moeljatno, 2000, Asas-asas Hukum Pidana, Jakarta: PT. Rineka Cipta.

Sudarto, 1983, Hukum Pidana dan Perkembangan Masyarakat, Sinar Baru, Bandung

Sudiarto dan Zaeni Asyhadie, Mengenal Arbitrase (Salah Satu Alternatif Penyelesaian Sengketa Bisnis), PT. Raja Grafindo Persada, Jakarta, 2004. 